\title{
Thirty years of relativistic self-consistent field theory for molecules: relativistic and electron correlation effects for atomic and molecular systems of transactinide superheavy elements up to ekaplutonium E126 with g-atomic spinors in the ground state configuration
}

Gulzari L. Malli

Published online: 31 July 2007

(C) Springer-Verlag 2007

Erratum to: Theor Chem Acc

DOI 10.1007/s00214-007-0335-1

The "Received" date of this article has been submitted incorrectly. The correct date is: 26 February 2007.

The online version of the original article can be found under doi:10.1007/s00214-007-0335-1.

G. L. Malli $(\bowtie)$

Department of Chemistry, Simon Fraser University,

Burnaby, BC, Canada V5A 1S6

e-mail:malli@sfu.ca 